\section{Visiting Fellowships in Astrophysics}

Applicatrons are invited by the Joint Institute for Laboratory Astrophysics, Boulder, Colorado, for visiting fellowships in theoretical astrophysics, low-energy atomic physies and other closely related areas. The fellowships, tenable for one year or possibly a shorter period, are awarded by the University of Colorado for the Institute, to provide an opportunity for persons actively contributing to these fields to visit the Institute to continue their studies and research in the field chosen by them. The amount of the stipend will normally equal the recipient's present academic salary adjusted to a twelve-month basis. The cost of transportation to and from Colorado for the recipient and his immediate family will also be met by the Institute. The closing date for application is January 15. Further information and forms of application can be obtained from the Secretary for Visiting Fellows, Joint Institute for Laboratory Astrophysics, University of Colorado, Boulder.

\section{The Vernon Prize in Industrial Psychology and Physi- ology}

The late Dr. H. M. Vernon made a bequest to tho National Institute of Industrial Psychology expressing the wish that the Institute should award a prize every second year to the investigator who, being a British subject and under the age of forty-five years, has in the opinion of the Council of the Institute done most valuable research work in service of industrial psychology or industrial physiology. The sixth award will be made in 1964 ; it will consist of approximately $£ 40$ in cash and a silver medal. Recommendations are invited of the names of workers in this field whom the Council should consider. Direct applications for the award may also be made. Recommendations or applications, supported by reference to published work and, if possible, copies of unpublished but relevant reports, should be made to the Director, National Institute of Industrial Psychology, 14 Welbeck Street, London, W.1, by February 29, 1964.

\section{The David Anderson-Berry Prize}

A David Anderson-Berry Silver-Gilt Medal, together with a sum of money amounting to not less than $£ 100$ (280 U.S. dollars), will be awarded by the Council of the Royal Society of Edinburgh during 1964. The Prize will be awarded for recent work on the effects of X-rays and other forms of radiation on living tissues. Published work will be taken into consideration if submitted to the Society with the application. In addition to direct application for the Prize, proposals can be made on behalf of others. Applications and proposals must be sent to the General Secretary, Royal Society of Edinburgh, 22-24 George Street, Edinburgh 2, Scotland, by March 31, 1964.

\section{Courses in Higher Technology}

THe wide variety of courses in advanced technology and management studies available to students in the London area is again presented in a bulletin prepared by the London and Home Counties Regional Advisory Council for Technological Education (Bulletin of Special Courses in Higher Technology, Management Studies and Commerce, 1963-64. Part 1: A.utumn Term. Pp. 134. London: London and Home Counties Regional Advisory Council for Technological Education, 1963. 4s.). The courses range from elements of law relating to civil and mechanical engineering at Battersea College of Technology, hydraulic and electrical control of injection moulding machinery at the Borough Polytechnic, a practical course in Elliott 803 autocode at Brunel College, the economics of tanker operation (shipping) at the City of London College, the Lebesgue integral at Hatfield College of Technology, solar heat gain at the National College for Heating, Ventilating, Refrigeration and Fan Engineering, gyrodynamics and inertial navigation at the Northampton College of Advanced Technology, rapid reading at Slough College, and carpet planning at the Technical College for the Furnishing Trades.

\section{Announcements}

WE regret to announce the death on November 13 of Dr. Margaret Murray at the age of 100 (Nature, 199, 119; 1963).

Srr William Penney, deputy chairman of the United Kingdom Atomic Energy Authority, has been appointed to succeed Sir Roger Makins as chairman of the Atomic Energy Authority when he retires in February 1964. Sir Roger Makins was appointed chairman of the Authority in 1960. Sir William Penney has been a member of the Authority since it was set up in $\mathbf{1 9 5 4}$.

The Plasties and Polymer Group has instituted an annual prize of $£ 50$ for the best paper submitted on any aspect of pure or applied polymer science. The competition is open to all British subjects under thirty years of age. Full details can be obtained from the Secretary, Plastics and Polymer Group, c/o Society of Chemical Industry, 14 Belgrave Square, London, S.W.1.

The Yearbook of the National Institute of Sciences of India, 1962, besides the report of the Council, to which are appended brief reports on research in physics, chemistry, botany, zoology and physiology, includes a brief account of the foundation of the Institute together with the lists of Fellows, membership of Council and committees, grants and publications and additions to the Library, as well as the rules and regulations (Pp. vi +251. New Delhi: National Institute of Sciences of India, 1963. Rs. 15.00).

THE 1963 Arthur Stanley Eddington Memorial Lecture entitled "Mind and Consciousness in Experimental Psychology" will be delivered by Dr. R. H. Thouless in Cambridge on November 29. Further information can be obtained from W. B. Harland, Arthur Stanley Eddington Memorial Trust, Gonville and Caius College, Cambridge.

THE annual meeting of the American Association for the Advancement of Science will be held in Cleveland, Ohio, during December 26-30. Further information can be obtained from $\mathrm{Mr}$. Kneeland A. Godfrey, American Association for the Advancement of Seience, 1515 Massachusetts Avenue N.W., Washington 5, D.C.

AN introductory course on "The Biology of the Skin" will be held in the School of Clinicel Research and Postgraduate Medical Teaching, University of Cambridge, during December 9-14. The course is intended primarily for registrars and postgraduate students at an early stage of their training in dermatology, but is also open to other medical practitioners. The fee for the course will be 5 guineas. Further information and forms of registration can be obtrined from the Secretary, Cambridge Univer. sity Medical School, Tennis Court Road, Cambridge.

THE forthcoming programme of the recently formed Society of Acoustic Technology (see Nature, 197, 23; 1963 ) will include: a meeting on "Acoustics", arranged jointly with the Liverpool and North Wales Branch of the Institute of Physies and the Physical Society at the University of Liverpool (December 11); a meeting to discuss "Practical Cases of Noise Reduction" at Salford (January 16); a meeting on "Noise in Ventilation Systems" at Manchester (February 21); a meeting on "Scale Model Techniques" at Salford (April 15); a conference on "Planning and Design for Protection from Noise" at Coventry (June 1-4); a conference on "Medical and Industrial Aspects of Hearing Loss" at the University of St. Andrews, Dundee (September 25-27). Further information can be obtained from Dr. P. Lord, Department of Pure and Applied Physics, Royal College of Advanced Technology, Salford. 